\title{
苦丁茶の成分と機能性
}

\author{
根岸 紀
}

(筑波大学大学院生命環境科学研究科)

\section{Health science of ku-ding-cha}

\author{
Osamu Negishi \\ Graduate School of Life and Environmental Sciences, University of Tsukuba, \\ Tsukuba Ibaraki, 305-8572, Japan \\ 干305-8572 茨城県つくば市天王台 1-1-1
}

\begin{abstract}
This paper describes the physiological functions of ku-ding-cha, a traditional bitter tea beverage that has been consumed in South China for a long time. Ku-ding-cha made from species in the genus Ilex, Aquifoliaceae and the genus Ligustrum, Oleaceae have been used in China as a diuretic and remedy for sore throat, weight loss and hypertension. Recent studies have demonstrated that triterpenes and triterpenoid glycosides in ku-ding-cha from the genus Ilex exhibit anti-arteriosclerosis, anti-obesity, anti-allergy and anti-cancer effects, and that phenylpropanoid glycosyl esters of phenylethanoid glycosides in ku-ding-cha from the genus Ligustrum exhibit anti-oxidative, anti-inflammatory, hepato-protective and anti-proliferative activities. Similar effects to those described above of the phenylethanoid glycosides and tea catechins are expected from ku-ding-cha of the genus Ilex, which contains a large amount of chlorogenic acids. We also demonstrated that ku-ding-cha has the ability to capture allyl mercaptan and allyl methyl sulfide in vivo. In conclusion, further investigations are necessary to more effectively use ku-ding-cha for maintaining our health.
\end{abstract}

\section{1.はじめに}

最近まで，お茶と言えば迷わず緑茶を頭に思い浮かべ ていたが，このごろは，緑茶，紅茶及びウーロン茶以外 にも，種々の植物葉を使用した『茶』が市販されている。 また, ペットボトル清涼飲料の種類も増加して健康飲料 『茶』が数多く見られ，茶と同等に扱われているように 思われる。本標題の「苦丁茶（ku-ding-cha）」は，日 本ではまだ馴染みが少ないが，主に中国の南部地方で茶 (Camellia sinensis を原料とする茶) の代用として古来 より飲用されてきた貴重な健康『茶』である1) 3)。

苦丁茶には 5 科 5 属 10 種の植物 ${ }^{1)}$, 3) が利用されている が，本稿では中国で多く流通している2 属の植物（モチ ノキ科 Ilex 属植物 ${ }^{4)}$ およびモクセイ科 Ligustrum 属植 物) 由来の苦丁茶（図1）を扱う。苦丁茶には, 中医学 では表 1 のような薬効が説明され, 治療に使用されてき た2)。表 1 の苦丁茶の効能は, 解熱, 解毒し, 炎症を治 し, さらに血液の循環を良くすることを表わしている。

\section{2. 苦丁茶の成分}

\section{（1）Ilex 属植物と Ligustrum 属植物}

苦丁茶の水色は, 緑茶と同様に淡い黄緑色から緑色 （Ilex 属植物由来の苦丁茶では青みが強い）であるが， 後に褐変化する。味は, 名前の通り非常に苦い。この色 や呈味に関係する成分は，苦丁茶をはじめ，その主な原

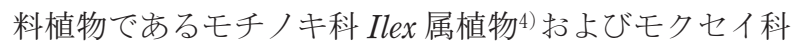
Ligustrum 属植物から抽出されて化学構造が明らかにさ れてきた。苦丁茶には, 緑茶の成分と同様な機能を持つ 種々の成分が含まれている5)。

図 2 は, 著者らが 2 属由来の苦丁茶からの抽出物を力 ラムクロマトグラフィーで分離したものであるが，それ ぞれに特徵的なパターンを示している。Ilex 属植物では, クロロゲン酸類 (CQA) の大きなピークが見られる他, 苦味の強い成分が含まれている。Ligustrum 属植物では, CQA 以外のピークとして, フェニルエタノイド配糖体 が含まれている。苦味は, 画分重量を考慮に入れると, 


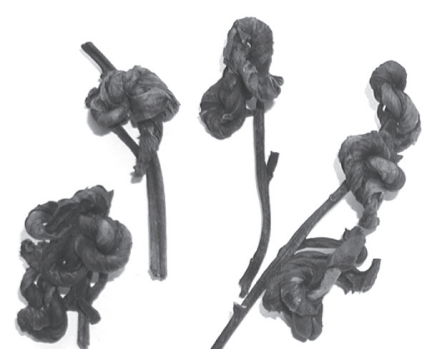

(a) モチノキ科植物由来の苦丁茶- 1

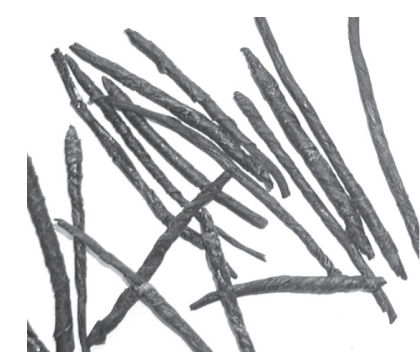

(b) モチノキ科植物由来の苦丁茶- 2

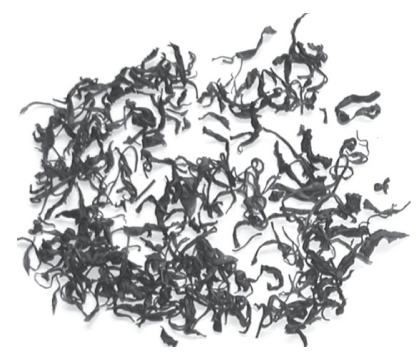

(c) モクセイ科植物由来の苦丁茶

図 1 主な苦丁茶の形状

モチノキ科植物（a， b ）には，I. cornuta (中国名では枸骨), I. kudingcha (苦丁茶冬青), I. latifolia (大葉冬青), およびモ クセイ科植物(c)には L. pedunculare (序梗女貞), L. purpurasens (紫茎女貞), L. japonicum (日本毛女貞), L. robustrum (粗壮女貞) が使用されている1),3)。

Ligustrum 属植物では Ilex 属植物の800分の 1 と弱い。

\section{（2）テルペン類と配糖体}

Ilex 属植物の強い苦味の主成分は, トリテルペンの配 糖体（サポニン）であり ${ }^{4), 6)}$, 多種類の化合物が単離さ
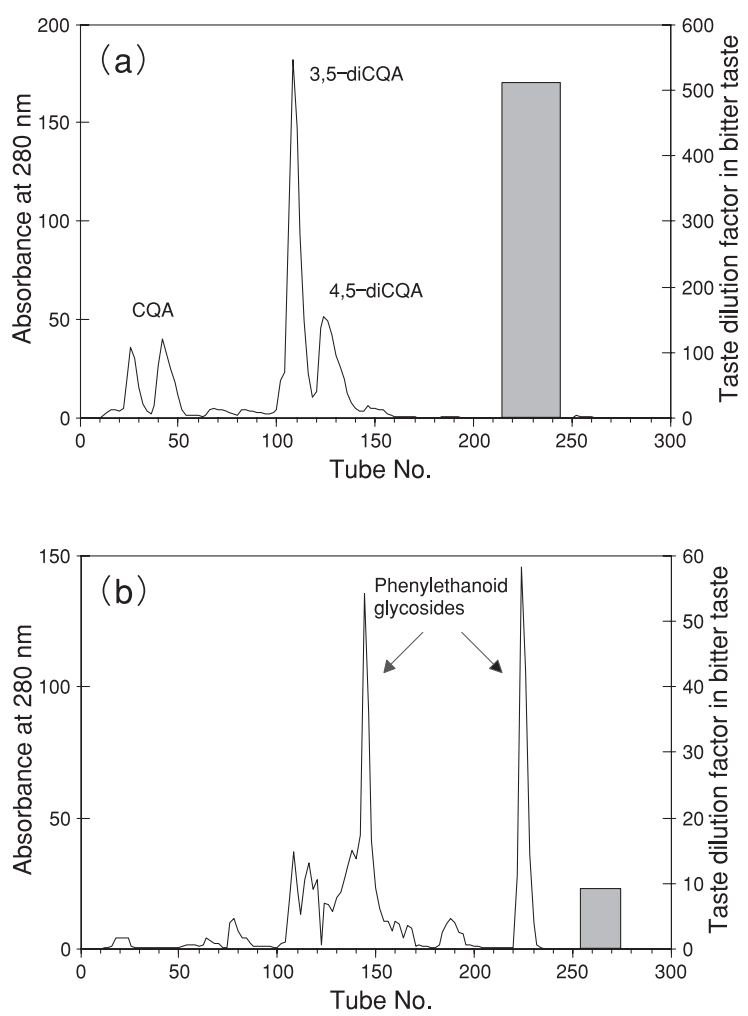

図 2 Wakosil 25C18カラムクロマトグラフィーによる苦丁茶 成分の分離

(a) Ilex 属由来の苦丁茶，(b) Ligustrum 属由来の苦丁茶。

クロロゲン酸類, フェニルエタノイド㧍よび苦味成分（棒グ ラフ）の分離。苦味の強度は, 凍結乾燥画分 $1 \mathrm{mg} / \mathrm{mL}$ の溶液 を希釈して苦味がなくなるまでの希釈率を表す。

れている(図 3 )。I. latifoliaの葉からの latifoloside A〜 $\mathrm{H}(\text { total } 880 \mathrm{mg} / \mathrm{kg})^{7), 8)}$, I. kudingcha からの ilekudinoside $\mathrm{A} \sim \mathrm{S}$ (total $110 \mathrm{mg} / \mathrm{kg}$ ), kudinoside $\mathrm{A}, \mathrm{C} \sim \mathrm{G}$ (total $132 \mathrm{mg} / \mathrm{kg}$ ), latifoloside (total $79 \mathrm{mg} / \mathrm{kg}$ ) がある ${ }^{9), 10)}$ 。 化合物名は色々であるが，基本的には ursolic acid（ $\mathrm{C}_{5}$ 単位のイソプレンが 6 個結合した $\mathrm{C}_{30}$ の五環式トリテル ペン）の誘導体にグルコース，アラビノース拉よびラフ イノースが 1 個から 5 個結合した構造である。さらに，

I. kudingchaから, 糖が結合していないトリテルペン (図 4 ) である ilekudinol A〜C (total $41 \mathrm{mg} / \mathrm{kg}$ ), ulmoidol $76 \mathrm{mg} / \mathrm{kg}$, ursolic acid 誘導体 (total $43 \mathrm{mg} / \mathrm{kg}$ )

表 1 中薬大辞典 $2{ }^{2}$ に記載されている苦丁茶の薬効と主治

\begin{tabular}{|c|c|c|}
\hline 項目 & 基原植物 & 薬効と主治 \\
\hline $\begin{array}{c}\text { 1.クテイチャ } \\
\text { [苦丁茶］ }\end{array}$ & $\begin{array}{l}\text { 主としてモチノキ科の植物, 枸 } \\
\text { 骨（ヒイラギモチI. cornuta), } \\
\text { 大葉冬青（タラヨウ I. latifolia） }\end{array}$ & $\begin{array}{l}\text { 風熱を散らす, 頭目を清める, 煩渇を除く, の効 } \\
\text { 能がある。頭痛, 歯痛, 目赤, 耳だれ, 熱病煩渴, } \\
\text { 伝染性下痢を治す。 }\end{array}$ \\
\hline $\begin{array}{c}2 \text {.クコツコウ } \\
\text { [枸骨葉 }]\end{array}$ & $\begin{array}{l}\text { モチノキ科の植物, 枸骨（ヒイ } \\
\text { ラギモチ I. cornuta }) \text { の葉 }\end{array}$ & $\begin{array}{l}\text { 肝腎を補う, 気血を養う, 風湿を去る, の効能が } \\
\text { ある。肺労咳嗽, 労傷出血, 腰膝瘘弱, リウマチ } \\
\text { による痺痛, 打撲傷を治す。 }\end{array}$ \\
\hline $\begin{array}{c}3 . \text { クチャヨウ } \\
\text { [苦茶葉 }]\end{array}$ & $\begin{array}{l}\text { モクセイ科の植物, 日本毛女貞 } \\
\text { (ケネズミモチ L. japonicum) }\end{array}$ & $\begin{array}{l}\text { 清熱する, 解毒する, の効能がある。急性結膜炎, } \\
\text { 口腔内潰瘍, 虫歯, 急性乳腺炎, 腫瘍による障害, } \\
\text { やけどを治す。 }\end{array}$ \\
\hline
\end{tabular}




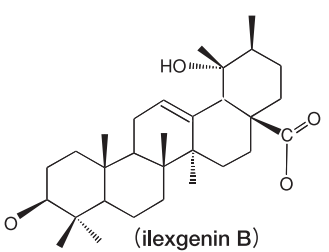

latifoloside $\mathrm{F}$
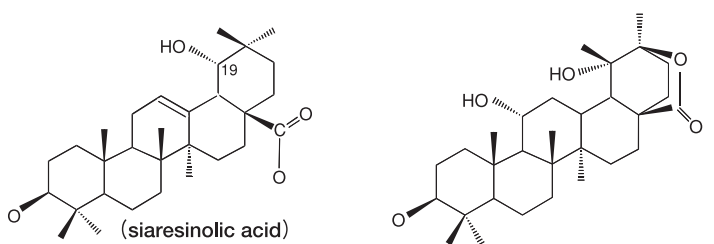

ilekudinoside $\mathrm{A}\left[{ }^{-\mathrm{b}} \mathrm{Rha}^{-19} \mathrm{OH}\right]$ ilekudinoside $\mathrm{H}\left[{ }^{\mathrm{a}} \mathrm{Glc}^{2} \leftarrow^{1} \mathrm{Glc}\right]$

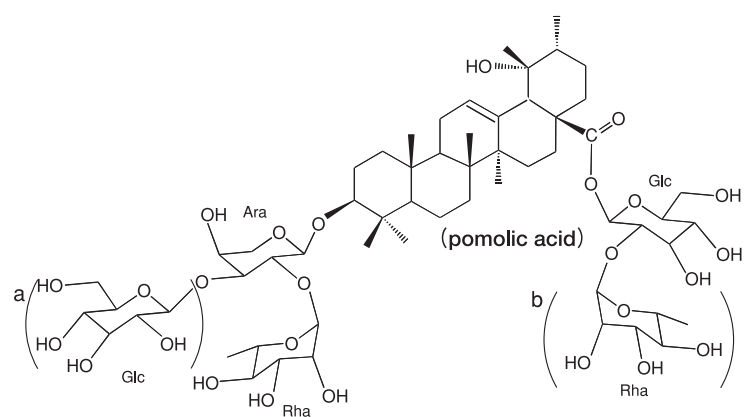

latifoloside $\mathrm{A}\left[{ }^{-\mathrm{a}} \mathrm{Glc}^{-\mathrm{b}} \mathrm{Rha}\right]$, ilekudinoside $\mathrm{F}\left[{ }^{\mathrm{a}} \mathrm{Glc}^{2} \leftarrow^{\mathrm{l}} \mathrm{Glc}\right]$, kudinoside $\mathrm{G}[-\mathrm{b} R \mathrm{Rha}]$

図 3 トリテルペン配糖体の構造式

トリテルペン（pomolic acid）部分が，上段のトリテルペンと置き換わり，また糖の数が異 なる構造の各種トリテルペン配糖体が単離されている（latifoloside $\mathrm{A} \sim \mathrm{H}$, ilekudinoside $\mathrm{A}$

$\mathrm{S}$, kudinoside $\mathrm{A} \sim \mathrm{G})$ 。表 3 の化合物を中心に表示した。 [ ]中の一は基本構造からのマイ ナスを， ‘は結合の追加様式を表わす。

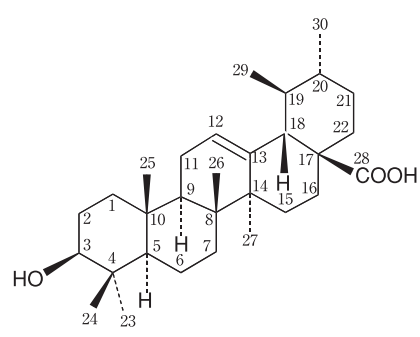

ursolic acid

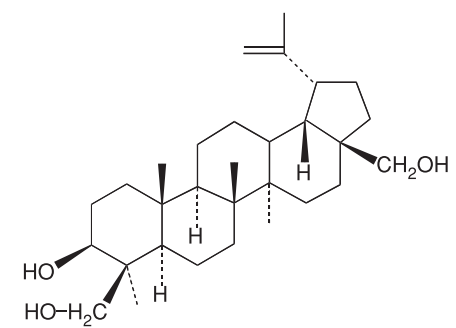

ilekudinol C

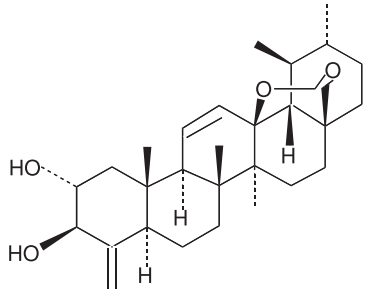

ilekudinol A

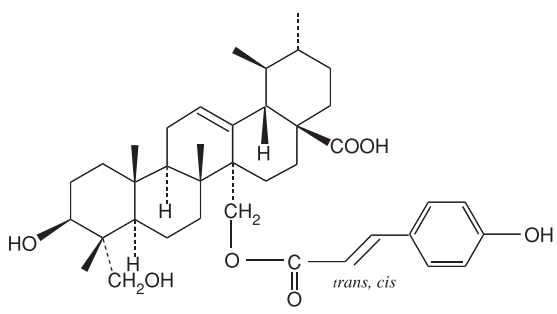

27-trans (cis)-p-coumaroyloxyursolic acid

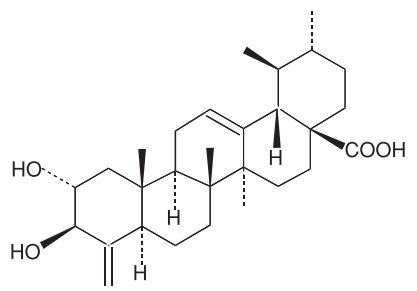

ilekudinol B

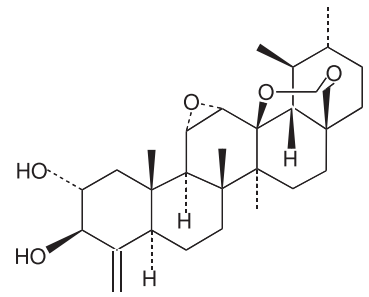

ulmoidol

図 4 トリテルペンの構造式 


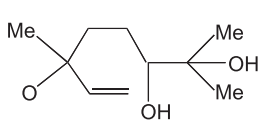

lipedoside B-VI

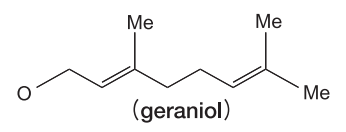

kudingoside $\mathrm{A}$<smiles>CC(=CCO)CC=CC(C)(C)O</smiles>

kudingoside $\mathrm{B}$

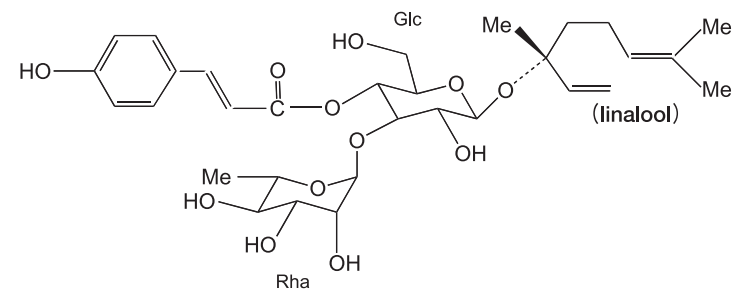

lipedoside B-III

図 5 モノテルペン配糖体の構造式

モノテルペン（linalool）部分が，上段のモノテルペンと置き換わった構造 の各種モノテルペン配糖体が単離されている (lipedoside B-I〜B-VI, kudingoside, ligurobustoside)。

が単離されている11)。他のトリテルペンの ursolic acid, $\beta$-amyrin, lupeol, taraxerol, uvaol やステロイドの $\beta$ sitosterol も報告されている4)。苦味の弱いL. pedunculareからは, モノテルペン（リナロールやゲラニオー

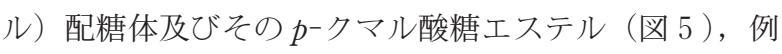
えば lipedoside B-I〜B-VI と anatolioside（total 350mg $/ \mathrm{kg}$ ）が単離されている12),13)。これらの括弧中の物質量 (total $\mathrm{mg} / \mathrm{kg}$ ) は精製・単離された量であり操作中の口
スもかなりあると考えられるので，実際に はもっと多く，2〜5倍量と推定される。 ursolic acid が $1 \%$ 前後含まれるという報 告もある ${ }^{14)}$ 。この成分は，多くの果実表面 のワックス様物質でもある。

\section{（3） ポリフェノール化合物}

苦丁茶の色や生葉の褐変に関わる成分は, ポリフェノール化合物のクロロゲン酸類 (図 6，3-CQA，4-CQA，5-CQA，3,4diCQA, 3,5-diCQA, 4,5-diCQA）であり, 苦丁茶やIlex 属植物の中で多いものでは 約 $25 \%$ も含まれている1)が, カテキン類 （図 6, C, EC, ECG, CG）は1.7\%程度で ある15）(茶のカテキン類は主に EC, ECG， EGC, EGCG であり 8 ～20\%含む5))。苦丁 茶はルチンを約 $0.4 \%$ と茶より多く含む15)。 また，L. pedunculare からフェニルエタノイド配糖体及 びそのp-クマル酸糖エステル（図 6 ), 例えば lipedoside A-I, A-II および osmanthuside B(total 260mg/kg) の単離 ${ }^{12}$ および L. purpurascens $の$ 葉中のフェニルエタ ノイド配糖体（及びそのp-クマル酸あるいはコーヒー 酸の糖エステル）含量も報告されている（acteoside, 2.1\%; ligupurpuroside A, 0.7\%; ligupurpuroside B, 0.3 $\%$; osmanthuside B, 0.5\%)16)。これらのポリフェノー<smiles>O=C(O[C@H]1Cc2c(O)cc(O)cc2O[C@H]1c1cc(O)c(O)c(O)c1)c1cc(O)c(O)c(O)c1</smiles>

(-) -epigallocatechin gallate (EGCG), $(-)$-epicatechin gallate $(\mathrm{ECG})[-\mathrm{OH}]$

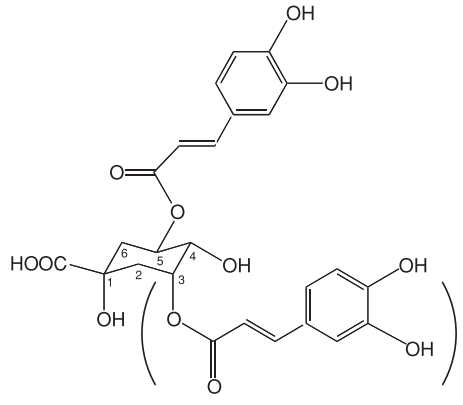

3, 5-dicaffeoylquinic acid (3,5-diCQA),

5-caffeoylquinic acid (5-CQA) [-caffeoyl]

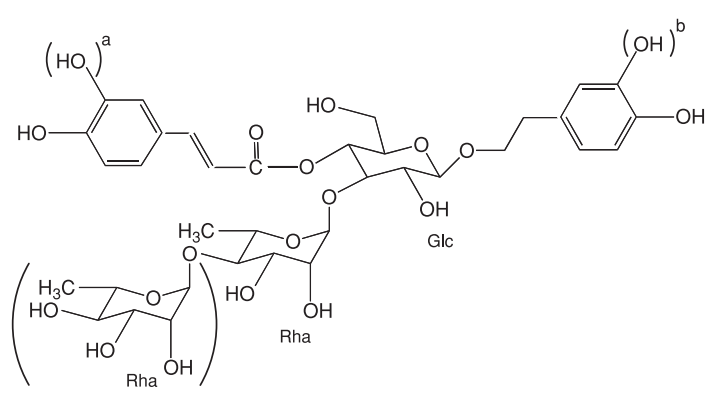

ligupurpuroside $\mathrm{A}$, ligupurpuroside $\mathrm{B}[-2 \mathrm{OH}]$, acteoside $[-\mathrm{Rha}]$, lipedoside $\mathrm{A}\left[-\mathrm{OH}^{\mathrm{a}}-\mathrm{Rha}\right]$ osmanthuside $\mathrm{B}[-2 \mathrm{OH}-\mathrm{Rha}]$

図 6 カテキン類, クロロゲン酸類, フェニルェタノイド配糖体の構造式 化合物名の後に示した $[$ ]中の一は基本構造からのマイナスを表わす。 
苦丁茶の成分と機能性

表 2 ポリフェノール含量と抗酸化能

\begin{tabular}{|c|c|c|c|c|}
\hline 苦丁茶 & $\begin{array}{c}\text { クロロゲン酸類 } \\
(\mathrm{mmol} / 100 \mathrm{~g})\end{array}$ & $\begin{array}{l}\text { フェニルエタ } \\
\text { ノイド配糖体 }\end{array}$ & $\begin{array}{c}\text { 総ポリフェノール** } \\
\quad(\mathrm{mmol} / 100 \mathrm{~g})\end{array}$ & $\begin{array}{c}\text { 抗酸化能*** } \\
(\mathrm{BHA} \text { 相当量, } \mathrm{mg} / 100 \mathrm{~g})\end{array}$ \\
\hline モチノキ科 & $66.3(25 \%)$ & $(-)$ & 74.5 & $580(3.0 \mathrm{mmol})$ \\
\hline モクセイ科 & 5.1 & $3.6 \% *$ & 69.6 & $370 \quad(2.0 \mathrm{mmol})$ \\
\hline
\end{tabular}

*文献16)より算出した。**クロロゲン酸を標準物質とした Folin-Ciocalteu 法により定量した。 *** $\beta$-カロテン退色法により測定した。

ル成分と抗酸化能の関係を表 2 に示した。苦丁茶はポリ フェノール成分を多く含むため，抗酸化能が高い。

\section{（4）その他の成分}

他の成分では, I. latifoliaの葉から作られた苦丁茶は, 緑茶に比べ遊離のアミノ酸やアスコルビン酸は僅かであ り，カフェインを含んでいない15)。抗酸化ミネラル成分 として, $\mathrm{Zn}, \mathrm{Mn}, \mathrm{Cu}$ および $\mathrm{Se}$ が注目される5)。 $\mathrm{Zn}, \mathrm{Mn}$, $\mathrm{Cu}$ は, 体内で活性酸素やフリーラジカルの無毒化に関 与するスーパーオキシドジスムターゼの構成成分であり， Se は, 有害過酸化脂質の分解に関与するグルタチオン ペルオキシダーゼの構成成分であるが，これらの成分が モチノキ科の苦丁茶には緑茶よりも多く含まれている17)。

\section{3. 各種成分の機能性}

\section{（1）緑茶と苦丁茶の機能性}

茶では, 数多くの機能性が精力的に調べられており5), 苦丁茶抢よび原料植物含有成分でも, 茶成分と構造が類 似した成分には同様の機能が期待される。ポリフェノー 儿類には, 抗酸化, 抗突然変異, 抗がん, 血圧上昇抑制, 抗腫瘍，抗炎症・抗アレルギー，抗菌，消臭などの作用 が，また，トリテルペン及びその配糖体には，抗喘息， 抗菌, 血圧降下, 抗アレルギー, 肥満防止などの作用が

表 3 動脈硬化抑制作用 ${ }^{9), 10), 18) ~}$

\begin{tabular}{l|c}
\hline \multicolumn{1}{c|}{ ACAT 阻害剂* } & $\mathrm{IC}_{50}\left(10^{-5} \mathrm{M}\right)$ \\
\hline Triterpene & \\
ilekudinol A & 15.4 \\
ilekudinol B & 4.4 \\
ilekudinol C & 32.8 \\
ulmoidol & 46.8 \\
23-hydroxyursolic acid & 6.4 \\
27-trans-p-coumaroyl ursolic acid & 7.3 \\
27-cis-p-coumaroyl ursolic acid & 19.4 \\
Triterpene glycoside & $(75.3)^{* *}$ \\
latifoloside A & $(185.8)^{* *}$ \\
ilekudinoside A & $(60.3)^{* *}$ \\
ilekudinoside F & \\
Monoterpene glycoside & 26.9 \\
lipedoside B-III & \\
Phenylethanoid glycoside & $>1000$ \\
osmanthuside B &
\end{tabular}

*各構造式は図 $3 \sim 6$ を参照。 **文献9)中の阻害濃度から比 例計算によって算出した。
考えられる。

\section{（2）トリテルペンと配糖体に関わる機能性}

前記成分の内のトリテルペン及びその配糖体には，小 腸管内でのコレステロールのエステル化に関わる酵素 acyl CoA cholesteryl acyl transferase（ACAT）を阻害し， コレステロールの吸収を低下させる作用がある5)。表 3 のように，遊離のトリテルペンに強い阻害作用が見られ

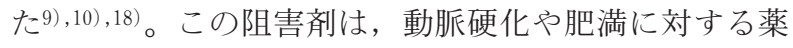
と期待されている。ウーロン茶サポニン ${ }^{5)}$ には, 膵リパー ゼ活性の阻害, 高脂肪食投与マウスの体重低下, さらに 脂質負荷後のラット血中中性脂肪含量の低下などの抗肥 満作用が報告されているが，苦丁茶においてもリパーゼ 活性の阻害作用が調べられている19)。ペパーミントやラ フマ(キョウチクトウ科の植物) の抽出物と同等の濃度 で阻害した。

ursolic acidなどのトリテルペンでは，抗菌，抗炎症， 抗がんの作用が報告されている20)。体内および食品中の スフィンゴミエリンというリン脂質は, 通常はスフィン ゴミエリナーゼという酵素で加水分解され蓄積せず低濃 度に維持されている。そのため, 本酵素は結腸のがん化 の阻害剤に提案されている。ursolic acidは, 特にアル カリスフィンゴミエリナーゼを活性化したため, 抗がん 作用を増強することが期待されている20)。さらに，苦丁 茶 (I. latifolia) 抽出物には, ヒスタミン遊離抑制作用 があり, IgE 抗体産生抑制作用のあるフコイダイン粉末 と併用することによる, 花粉症の眼, 鼻, 喉の各症状改 善効果を請求した特許が公開されている21)。2 月から 4 月におけるヒトボランティア試験により各症状に対し 90 $\%$ 前後の有効性が示された。抗アレルギー作用を示す苦 丁茶中の有効成分としては, 茶同様にサポニンが推定さ れる。スギ花粉症の著者が2007年 1 月下旬から 3 月初め に本作用を実践した（毎日, 昼食後から夕方までに, 図 1 - (b ), Ilex 属植物由来の苦丁茶 1 本を約 $100 \mathrm{~mL} \times 5$ 回の湯でいれて飲んだ）結果, 花粉症の症状（くしゃみ, 鼻水, 鼻づまり等）がほとんど現れなかった。その後, 花粉飛散ピーク時期に 1 日間中止すると, 次の午前中に は, くしゃみ, 鼻水が激しく出たため, 再び昼から苦丁 茶を飲んだ。その結果, 翌日からほとんど症状は現れな かったので, 苦丁茶の効果はあると思われる。 


\section{（3） ポリフェノール化合物に関わる機能性}

Ligustrum 属植物のフェニルエタノイド配糖体及びそ のp-クマル酸あるいはコーヒー酸の糖エステルには, 抗酸化性, 抗炎症作用, 肝臓保護作用, 腫瘍細胞の増殖 抑制活性が報告されている。スーパーオキシド捕捉活性 脂質過酸化及び溶血反応の阻害活性が高かった $L$. robustum 由来苦丁茶に抢ける配糖体が高濃度なフラク ションでは， $0.5 \mathrm{~g} / \mathrm{kg}$ （マウス）の量に抢いて抗炎症薬 である Indomethacin（0.1 g/ kg） とほぼ同等の抗炎症

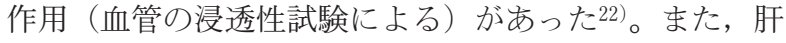
臓疾患の治療薬である Silymarin と同様の肝機能保護作 用 $\left(\mathrm{CCl}_{4}\right.$ による肝障害の治療効果，すなわち，GOT， GPT の低下および肝蔵組織における脂肪の蓄積と細胞 の壊死の減少・改善) がラットで認められている22)。さ らに， やligupurpuroside A（図 6 ）では，腫瘍細胞である B16F10（マウスメラノーマ), HeLa（ヒト子宮頸癌細 胞)，MK-1（ヒト腸癌細胞）に対する強い増殖 抑制活性が認められた ${ }^{23)}$ 。これは，抗腫瘍薬であ る5-fluorouracil とほぼ同等の増殖抑制濃度であ った。

クロロゲン酸類においても，カテキン類やフェ ニルエタノイド配糖体などと同様に，抗酸化性， 抗変異原性をはじめ, 抗がん, 血圧降下, 抗炎症 作用，糖尿病改善効果などが期待されている24)。

\section{（4）生体内消臭作用}

著者らは，Ilex 属植物由来の苦丁茶抽出液を用 いて生体内消臭作用を調べた。図 7 のよう，ニン ニクを摂取すると悪臭のアリルメルカプタン

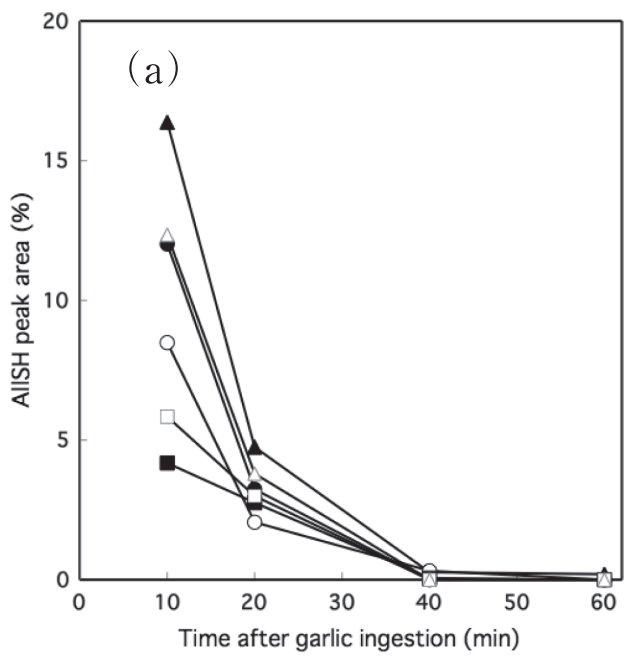

(AllSH) が生成し，さらに，メチル化してアリルメチ ルスルフィド（AllSMe）となり，不快臭が持続する。 ここで，苦丁茶を摂取すると苦丁茶中のポリフェノール 成分が自動酸化されてキノン構造になり，AllSH と付 加反応を起こして（A11SH を捕捉して）消臭される。 実際の生体内消臭結果（図 8 ）では，ニンニクを摂取終 了後 (0 時)，5分間で茶を飲み，その 5 分後の経過時 間10分の時点で，苦丁茶では AllSH がコントロールの 水より約 $3.5 \%(-13 \mathrm{ppb})$ 軽減されていた。効果は, 緑茶（+16ppb）よりアリルメルカプタン消去能が強く, 紅茶 $(-28 \mathrm{ppb})$ やウーロン茶 $(-22 \mathrm{ppb})$ より も弱い という結果であった。また, AllSMeの消去に関して苦 丁茶では経過時間10分で水より約 $17 \%(-48 \mathrm{ppb})$ の軽

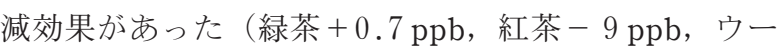

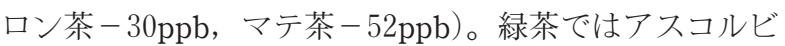
ン酸が多く含まれているためにカテキン類の酸化が阻止 され，消臭作用がなかったと考えられる。さらに，尿中
ニンニク

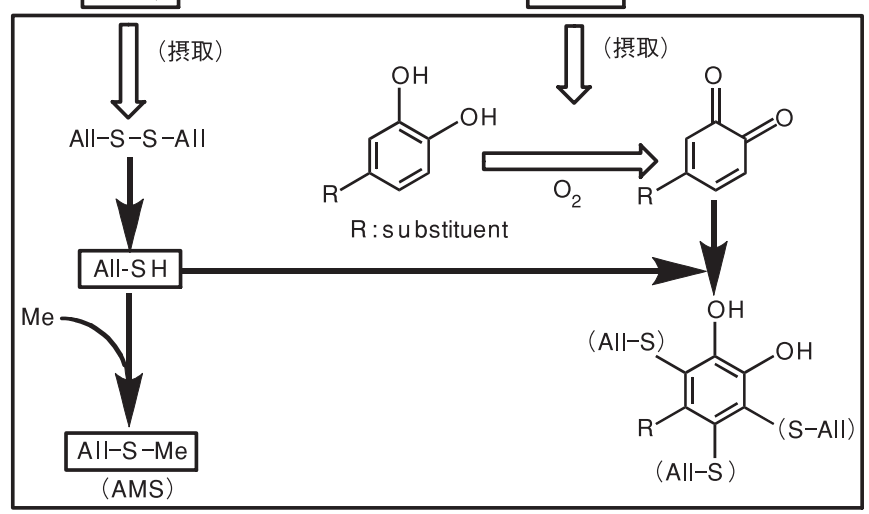

図 7 不快臭の発生と捕捉

\section{図 8 生体内における不快臭の軽减}

被験者（51歳，男）は，昼食時に米飯 $350 \mathrm{~g}$ とともに $5 \mathrm{~g}$ のニンニクペースト入みそ汁 $300 \mathrm{~mL}$ を食べた後 ( 0 時)，5 分間で茶類を飲んだ。その後，経時的に呼気を捕集し GCで分析した。また，同時に尿を採取 し，そのヘッドスペースガスを分析した。(a) AllSH (360ppb/100\%)，(b) AllSMe (280ppb/100\%)。

○, コントロール (水); $\bigcirc$, 苦丁茶 $(1 \mathrm{~g} / 300 \mathrm{~mL}) ; \boldsymbol{\Delta}$, 緑茶 $(3 \mathrm{~g} / 300 \mathrm{~mL}) ; \triangle$, マテ茶 $(3 \mathrm{~g} / 300 \mathrm{~mL})$; 口, 紅茶 $(3 \mathrm{~g} / 300 \mathrm{~mL}) ; \square$, ウーロン茶 $(3 \mathrm{~g} / 300 \mathrm{~mL})$ 
への AllSMe の排泄量に関しては，比較的苦丁茶で低か った（図 8-b)。以上の生体内消臭の解析から, 苦丁茶 中のクロロゲン酸類の自動酸化の程度は弱く, 悪臭消去 効果もあまり高くはないという結果になったが, 苦丁茶 の摂取量を増やすことにより, さらに悪臭軽減効果が期 待される11,25)。

\section{4. 終わりに}

以上のように，苦丁茶には健康に良い成分として，ク ロロゲン酸類, フェニルエタノイド配糖体コーヒ一酸の 糖エステル，トリテルペンとその配糖体（サポニン）が 含まれ, 緑茶と同様の各種機能性が期待されているが, 今後, 実際の効果 (人体への作用) をさらに調査研究す る必要がある。苦丁茶の治療的な使用ではなく, 予防的 な利用を抢勧めしたい。

なお, 本総説の生体内消臭作用に関する部分は, 平成 17 年度 18 年度科学研究費補助金採択課題『食品中の $\mathrm{PP}-\mathrm{PPO}$ 反応系による口臭・体臭の消去』の成果の一 部である。

\section{引用文献}

1）根岸 紀: ポリフェノール化合物とポリフェノールオキ シダーゼの反応系を利用した消臭方法. ソフト・ドリンク 技術資料，No.145，21 33 (2005).

2)上海科学技術出版社・ 小学館：1123クコッヨウ, 1169ク チャヨウ, 1172クテイチャ. 中薬大辞典. 小学館, 1, pp. 571〜572, 593〜595 (1985).

3）横澤隆子, 野中源一郎: 苦丁茶を探る. FOOD Style 21, $7,77 \sim 80$ (2003).

4) Alikaridis, F.: Natural constituents of Ilex species. J. Ethnopharmacology, 20, 121-144 (1987).

5）村松敬一郎, 小國伊太郎, 伊勢村護, 杉山公男, 山本 (前田) 万里 : 茶の機能一生体機能の新たな可能性. 学会出 版センター (2002).

6) Ochi, M., Ochiai, K. and Nagao, K.: Bitter principles of Aquifoliaceae. III. The structures and stereochemistry of three aglycones obtained by the hydrolysis of latifoloside A, a bitter glycoside from Ilex latifolia Thunb. Bull. Chem. Soc. Japan, 48, 937-940 (1975).

7) Ouyang, M. A., Wang, H. Q., Liu, Y. Q. and Yang, C. R.: Triterpenoid saponins from the leaves of Ilex latifolia. Phytochemistry, 45, 1501-1505 (1997).

8) Ouyang, M. A., Liu, Y. Q., Wang, H. Q. and Yang, C. R.: Triterpenoid saponins from Ilex latifolia. Phytochemistry, 49 , 2483-2486 (1998).

9) Nishimura, K., Miyase, T. and Noguchi, H.: Triterpenoid saponins from Ilex kudincha. J. Nat. Prod., 62, 1128-1133 (1999).

10) Tang, L., Jiang, Y., Chang, H. T., Zhao, M. B., Tu, P. F., Cui, J. R. and Wang, R. Q.: Triterpene saponins from the leaves of Ilex kudingcha. J. Nat. Prod., 68, 1169-1174 (2005).
11) Nishimura, K., Fukuda, T., Miyase, T., Noguchi, H. and Chen, X. M.: Activity-guided isolation of triterpenoid acyl CoA cholesteryl acyl transferase (ACAT) inhibitors from Ilex kudincha. J. Nat. Prod., 62, 1061-1064 (1999).

12) He, Z. D., Ueda, S., Akaji, M., Fujita, T., Inoue, K. and Yang, C. R.: Monoterpenoid and phenylethanoid glycosides from Ligustrum pedunculare. Phytochemistry, 36, 709-716 (1994).

13) Tian, J., Zhang, H. J., Sun, H. D., Pan, L. T., Yao, P. and Chen, D. Y.: Monoterpenoid glycosides from Ligustrum robustum. Phytochemistry, 48, 1013-1018 (1998).

14) Guo, Y., Cui, Y., Zhou, J. and Yan, Y.: Quantitative determination of ursolic acid in folium Ilex cornuta gathered in different seasons. Zhongguo Zhongyao Zazhi, 20, 591-592 (1995).

15) Liang, Y., Ma, W., Lu, J and Wu, Y.: Comparison of chemical compositions of Ilex latifolia Thumb and Camellia sinensis L. Food Chem., 75, 339-343 (2001).

16) Wong, I. Y. F., He, Z. D., Huang, Y. and Chen, Z. Y.: Antioxidative activities of phenylethanoid glycosides from Ligustrum purpurascens. J. Agri. Food Chem., 49, 3113-3119 (2001).

17）翠川美穂, 藤原しのぶ, 佐々木弘子, 菅原龍幸 : 苦丁茶 の茶葉打よび浸出液中のミネラル含量. 日本食生活学会第 32回大会講演要旨集, p. 4 (2006).

18) Fukuda, T., Kitada, Y., Chen, X. M., Yang, L. and Miyase, T.: Two new monoterpene glycosides from ku-ding -cha. Inhibitors of acyl-CoA: cholesterol acyltransferase (ACAT). Chem. Pharm. Bull., 44, 2173-2176 (1996).

19）田村幸吉, 曽我部友紀：リパーゼ阻害剤。日本国特許庁, 特開2003-26585 (2003).

20) Andersson, D., Nilsson, A. and Duan, R. D.: Ursolic acid and other pentacyclic triterpenoids stimulate intestinal alkaline sphingomyelinase in vitro. Eur. J. Lipid Sci. Technol., 108, 103-108 (2006).

21）谷 久典, 野口大之, 大石一二三 : 抗アレルギー作用を 有する混合物及びこれを含有する食品. 日本国特許庁, 特 開2003-300887 (2003).

22) Lau, K. M., He, Z. D., Dong, H., Fung, K. P. and But, P. P. H.: Anti-oxidative, anti-inflammatory and hepato-protective effects of Ligustrum robustum. J. Ethnopharmacology, 83, 63-71 (2002).

23) Kinjo, J., Nagao, T., Okawa, M., Nohara, T., Yang, C. R., Nonaka, G. and Okabe, H.: Antiproliferative activity of phenylpropanoid ester glycosides from Ligustrum purpurascens. Natural medicines, 56, 136-138 (2002).

24) Islam S.: Sweetpotato (Ipomoea batatas L.) leaf: its potential effect on human health and nutrition. J. Food. Sci., 71, R 13-R21 (2006).

25) Negishi, O. and Negishi, Y.: "In vivo deodorisation with caffeoylquinic acid derivatives”, Flavour Science-Recent advances and trends. In Developments in Food Science 43; W.L.P. Bredie and M.A. Petersen, Eds.; Elsevier: Amsterdam, The Netherlands, pp.105-108 (2006).

本稿は, 第33回研究集会における発題講演をまとめたものである。 